\title{
The Effect of Timolol on the Iris Vascular Tone in Rats
}

\author{
Dragos-Constantin Lunca ${ }^{1,3}$, Horia Paunescu' ${ }^{1}$, Mihnea Costescu', Laurentiu Coman², Ion Fulga
}

\begin{abstract}
We investigated, in rats, the existence of a cathecolaminergic vasodilator tone in iris vessels, using as a pharmacological tool, timolol, a non-selective $\beta$-blocker, devoided of intrinsic sympathomimetic activity. The use of $2.5 \mathrm{mM}$ timolol in conjunctival instillation reduced the diameter of the iris arteries without having an effect on the size of the iris veins diameter. Our results suggest the existence of a catecholaminergic vasodilator tone in rat's iris arteries, not in iris veins, probably achieved via $\beta 2$-adrenergic receptors.
\end{abstract}

Keywords: timolol, iris vessels, rats, vasodilator

\section{Rezumat}

S-a cercetat existența unui tonus vasodilatator catecolaminergic la nivelul vaselor iriene la șobolan, utilizând drept instrument farmacologic, timololul, un $\beta$-blocant neselectiv, fără activitate simpatomimetică intrinsecă. Folosirea timololului 2,5 mM în instilații conjunctivale a redus diametrul arterelor iriene, fără a avea un efect asupra calibrului venelor iriene. Rezultatele noastre sugerează existența, la șobolan, a unui tonus vasodilatator catecolaminergic la nivelul arterelor iriene, nu și la nivelul venelor iriene, probabil realizat prin intermediul receptorilor $\beta 2$-adrenergici.

Cuvinte-cheie: timolol, vase iriene, șobolani, vasodilatator

\section{INTRODUCTION}

Vascular tone is generally controlled by both the humoral component and the neuro-vegetative component. Regarding the second one, catecholaminergic sympathetic innervation of blood vessels is almost a rule in the body ${ }^{1,2}$.

It is known that the iris is sympathetically innervated, both at the level of the iris dilator muscle ${ }^{1,2}$ and at the level of iris blood vessels ${ }^{3}$. Cathecolamines are responsible for vasoconstriction and, in some vascular beds, vasodilation. Stimulation of neuropeptide $\mathrm{Y}$ positive nerve fibers, belonging to sympathetic postganglionic neurons from the upper cervical node caused a decrease in the iris blood flow ${ }^{4}$ (vasoconstriction).

\footnotetext{
' Department of Pharmacology and Pharmacotherapy, Faculty of Medicine, "Carol Davila" University of Medicine and Pharmacy, Bucharest, Romania

2 Department of Physiology, Faculty of Pharmacy, "Carol Davila" University of Medicine and Pharmacy, Bucharest, Romania

${ }^{3}$ Ambulatory Care Center, „Dr. Carol Davila” Central Military

Emergency University Hospital, Bucharest, Romania
}

It is known that neuropeptide $\mathrm{Y}$ is a cotransmitter of noradrenaline. Regarding the possibility of a catecholaminergic vasodilator tone in iris vessels, the results are contradictory. Propranolol administered conjunctivally, in vivo, causes iris vessels constriction in rabbits, and timolol, in vitro, antagonized the possible vasodilator effect of isoprenaline, quantified by the decrease of permeability to carbon particles, in rats' iris vessels ${ }^{6}$. Opposite to those mentioned above, timolol in conjunctival instillations produces, in vivo, dilation of iris vessels, in rhesus monkeys ${ }^{7}$.

The aim of this study was to evaluate in vivo, in rats, the possible existence of a catecholaminergic vasodilator tone produced by $\beta_{2}$ adrenergic receptors, in iris vessels.

\section{Corresponding author.}

Horia Paunescu, Faculty of Medicine, $8^{\text {th }}$ Eroilor Sanitari Boulevard, $5^{\text {th }}$ District, Bucharest, Romania.

E-mail: phpaunescu@yahoo.com 


\section{MATERIALS AND METHODS}

We used one group of 6 adult albino male rats weighting between 280 and 320 grams, brought in the laboratory with 4 days before the experiment and with access ad libitum to water and food. The experiments were performed between 9:00 and 17:00. The animals were used once and the recordings were made at one eye, the right one. The experiments were carried out with the approval of the Local Ethics Committee of "Carol Davila" University of Medicine and Pharmacy, Bucharest, Romania.

The substances used were 10\% ketamine (CP-Ketamine 10\%, CP-Pharma, Germany, for veterinary use), distilled water (Zentiva SA, Romania), timolol 0.5\% (Timolol, Eipico, $5 \mathrm{mg} / \mathrm{ml}$ eye drops, solution, Eipico Med SRL, Romania).

Experimental procedure: Animals were anesthetized with $10 \%$ ketamine $(0.2 \mathrm{ml} / 100 \mathrm{~g}$ weight $)$ and after 15 minutes they were placed in left lateral decubitus for optimal visualization of the right eyeball, and the eyelids were maintained opened by manual traction. The right eye was viewed at $400 \times$ maximum magnification, with an optical system made of NIKON objective lens and an adapter (NAVITAR 1X Adapter 1-6015) connected to a CCD camera (TOSHIBA-IK642E) and a Logilink video-grabber analog-to-digital converter USB 2.0. For illumination, we used a ring-shaped (circular) cold light source (Dolan-Jenner Industries Inc.FiberLite Series 180). Magnification and lighting conditions were not altered during the recordings. The recording of the eyes lasted 11 minutes. For each analyzed iris, image captures were made, and arteries and veins diameters were measured at the following times: $t_{0}=0$ seconds, $t_{2}=120$ seconds, $t_{3}=180$ seconds, $t_{4}=210$ seconds, $t_{5}=300$ seconds, $t_{7}=420$ seconds, $\mathrm{t}_{8}=480$ seconds, $\mathrm{t}_{9}=510$ seconds, $\mathrm{t}_{10}=600$ seconds, $\mathrm{t} 11=630$ seconds after the start of the recording. At $\mathrm{t}_{1}=30$ seconds, distilled water was administered, and at $\mathrm{t}_{6}=330$ seconds, the $2.5 \mathrm{mM}$ timolol solution was administered. Under these conditions, the diameters of the arteries and veins were practically measured at the begining of the recording, before instillation of distilled water, then at 90 seconds, 150 seconds, 180 seconds, 270 seconds after the administration of distilled water, and at 90 seconds, 150 seconds, 180 seconds, 270 seconds and 300 seconds after the administration of 2.5 $\mathrm{mM}$ timolol. Measurements were made in pixels at the intersection between an artery and a vein, the smaller sized vessel located anteriorly at the intersection was considered an artery, and the larger vessel, located posteriorly at the intersection, was considered a vein. We measured vessel diameters on grayscale images (see figure 1) using ImageJ $1.51 \mathrm{j} 8$ software with the plugin named Diameter ${ }^{8}$. At each moment, four arterial measurements and vein measurements were made for each evaluated eye. For each determination and each moment, the percent variation of the vascular diameter, relative to intial diameter at moment $\mathrm{t}_{0}$ was calculated using the formula:

$$
D_{r e l}=\frac{D_{x}-D_{0}}{D_{0}} \times 100
$$

where $\mathrm{D}_{\text {rel }}$ is the percentage change in diameter in relation to moment $t_{0}, D_{x}$ is the vessel's diameter in pixels at the moment of measurement and $D_{0}$ is the diameter in pixels of the vessel at moment $t_{0}$. For each moment, the relative diameter, in percent, and standard error were calculated. Subsequently, the statistical significance of the differences between each moment of the determination and the moment $t_{0}$ was determined. The statistical significance was calculated using $t$-student test, the paired variant (each analyzed eye was his own control). Differences were considered statistically significant, if $\mathrm{p}<0.05$.

\section{RESULTS}

The evolution in time of the relative diameter (in percent) of the iris vessels is shown in Figure 2, Figure 3 and Table 1 . The administration of $2.5 \mathrm{mM}$ timolol after distilled water produced a decrease in the iris arteries diameters by $8.25 \%+/-2.46 \%$ at moment $t_{7}$, by $9.22 \%+/-2.82 \%$ at moment $t_{8}$, by $9.26 \%+/-2.53 \%$ at moment $t_{10}$, and by $10.58 \%+/-3.50 \%$ at moment $t_{11}$. These values are statistically significant in relation to moment $\mathrm{t}_{0}, \mathrm{p}<0.05$.

Administration of the $2.5 \mathrm{mM}$ timolol solution did not cause significant changes in the relative diameter of iris veins. Distilled water did not cause statistically significant changes of the relative diameters of iris arteries or veins.

\section{DISCUSSIONS}

For standardisation purpose, the terms iris arteries and veins, instead of arterioles and venules were used.

The $2.5 \mathrm{mM}$ timolol concentration was chosen, because at this molar concentration, we obtained pertinent results in experiments investigating the role of histamine and serotonin in regulating the iris vascular motricity (unpublished results). 
Figure 1. Grayscale images captured from the 11 minutes recording of the same eye, at moment $t_{0}$ and $t_{8}$.

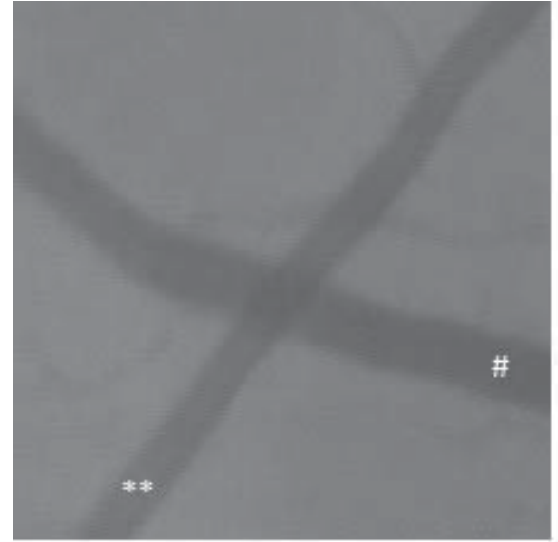

initial moment - to (before instillation of distilled water)

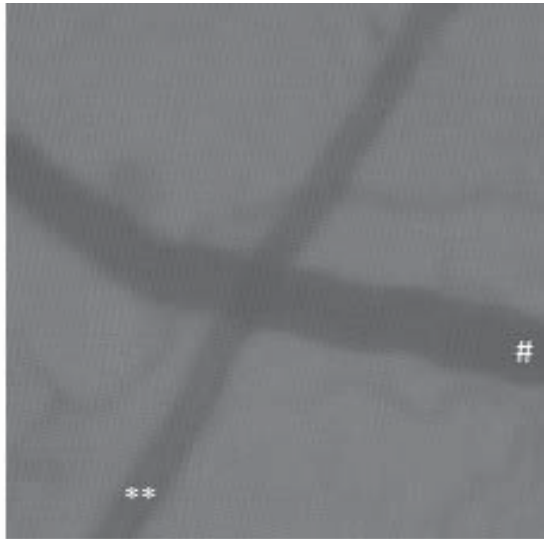

ts moment - at 150 seconds after timolol $2,5 \mathrm{mM}$ instillation
** iris artery

\# iris vein
Some mentions are needed to be made. Our aim was to verify the existence of a tonic regulation, not a phasic regulation of iris vessels motricity. There are two conditions for the tonic control of a body structure function: the existence in permanence or, in any case, over long periods of time in that structure, of a minimal endogenous biologically active substance concentration, as well as an adequate density of the receptors for that substance, which acts as an agonist. Administration of an antagonist of those receptors results in opposite effects to those of the agonists, if there is tonic control. The phasic control supposes that the antagonist produces no effect, but it will be able to prevent the physio- logical agonist action, if the agonist will be present in that structure?

Our results show that administration of timolol produces statistically significant vasoconstriction in the iris arteries, without statistically significant effect in iris veins. Thus, we can state that there is a vasodilatory catecholaminergic tone in iris arteries. No such vasodilator catecholaminergic tone could be observed in iris veins.

We supposed that vasoconstriction produced by timolol in the arterial territory of the iris could be produced by blocking the vascular adrenergic $\beta_{2}$ receptors.
Figure 2. Time evolution of iris artery relative diameters after administration of distilled water at moment $t_{1}$ and, subsequently, of $2.5 \mathrm{mM}$ timolol at moment $t_{6}$. On the horizontal are the moments at which determinations were made, the height of the columns represents the percentage of change in the relative vascular diameter (* $p<0.05)$.

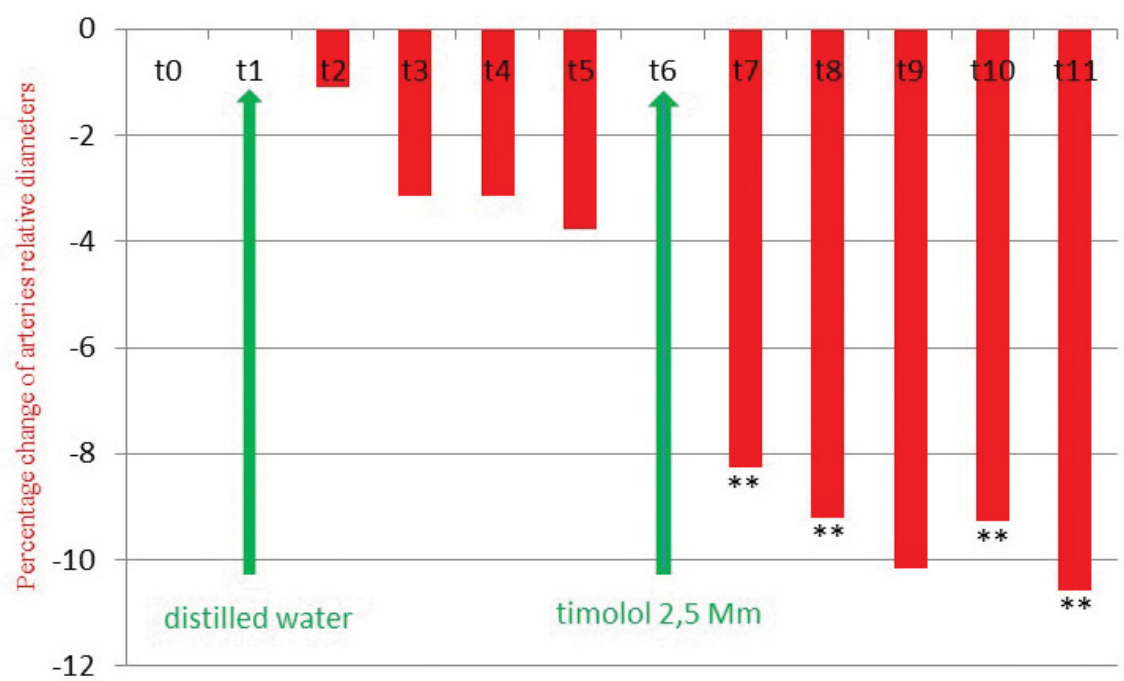


Figure 3. Time evolution of iris veins relative diameters after administration of distilled water at moment $t_{1}$ and subsequently of $2.5 \mathrm{mM}$ timolol at moment $\mathrm{t}_{6}$. On the horizontal are the moments at which determinations were made, the height of the columns represents the percentage of change in the vascular relative diameter. There were no statistically significant changes.

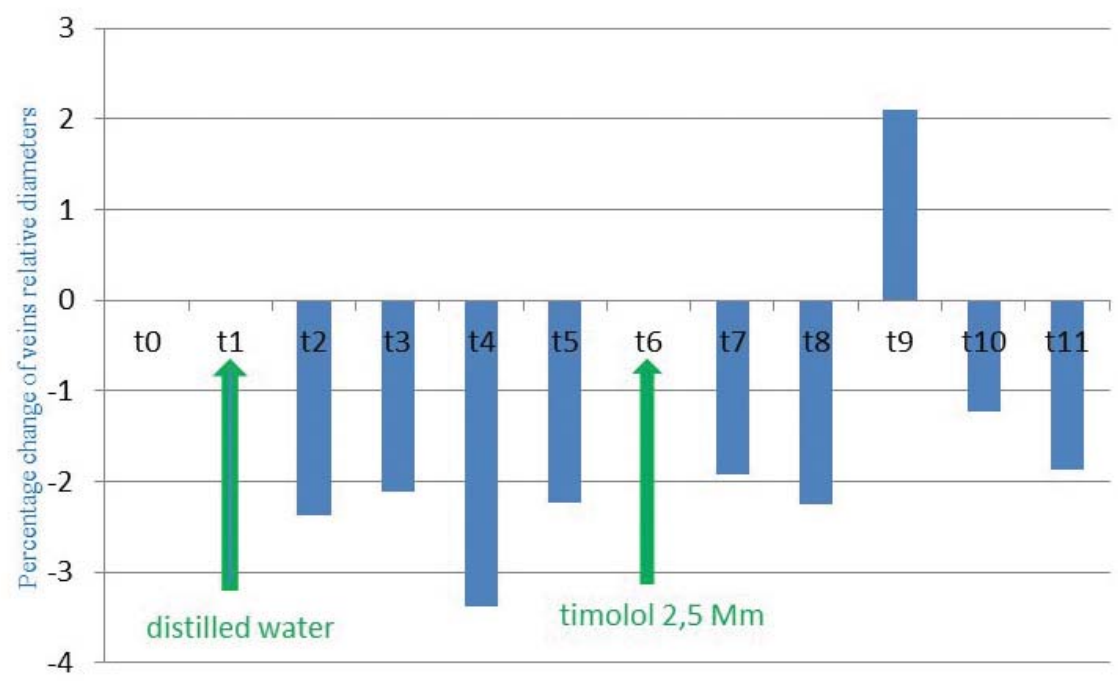

It is plausible to have vascular $\beta_{2}$ adrenergic receptors in the iris arteries. The tonic stimulation of these $\beta_{2}$ adrenergic receptors can be achieved either by adrenaline or noradrenaline as endogenous biologically active substances. Considering that adrenaline has greater affinity (about 6 times higher) for $\beta_{2}$ adrenergic receptors than noradrenaline ${ }^{11}$, and that we have used ketamine as a general anesthetic, a substance that increases, globally, the adrenergic tone of the body and causes the release of large amounts of adrenaline from the adrenal medulla in the blood ${ }^{11}$, adrenaline may had been the major contributer to this cathecolaminergic tone. Blocking the action of adrenaline on $\beta_{2}$ adrenergic receptors in iris arteries, probably, determined the vasoconstriction observed with timolol. But, there is a mention to be made: the fact that we didn't find a cathecolaminergic vasodilatatory tone in iris veins could be determined by two factors: there aren't $\beta_{2}$ adrenergic receptors in veins or there is no agonist for these receptor. Malmfors T. found that, in rat, only the arteries appear to be innervated ${ }^{3}$, meaning that noradrenaline may not be present in veins, but could be present in arteries.

\section{CONCLUSIONS}

The use of $2.5 \mathrm{mM}$ timolol in conjunctival instillations, in rats, reduced the diameter of iris arteries, without

Table 3. Time evolution of iris arteries and veins relative diameters after administration of distilled water at moment $t_{1}$ and, subsequently, of $2.5 \mathrm{mM}$ timolol at $\mathrm{t}_{6}$. For each moment of the determination, it is highlighted the mean relative diameter $+/$ - standard error, in percent.

\begin{tabular}{|c|c|c|c|c|}
\hline & \multicolumn{2}{|l|}{ Iris arteries } & \multicolumn{2}{|l|}{ Iris veins } \\
\hline The moment of measurement & $\begin{array}{c}\text { The mean relative diameter in } \\
\text { percent+/- standard error }\end{array}$ & $p$ (t-test) & $\begin{array}{c}\text { The mean relative diameter in } \\
\text { percent+/- standard error }\end{array}$ & $\mathrm{p}(\mathrm{t}$-test) \\
\hline $\mathrm{t}_{0}=0 \mathrm{sec}$ (control) & 0 & & 0 & \\
\hline$t_{1}=30 \mathrm{sec}$ & \multicolumn{4}{|c|}{ Conjunctival instillation of distilled water } \\
\hline$t_{2}=120 \mathrm{sec}$ & $-1.09+/-1.2$ & 0.41 & $-2.37+/-1.26$ & 0.12 \\
\hline$t_{3}=180 \mathrm{sec}$ & $-3.16+/-1.91$ & 0.16 & $-2.11+/-2.15$ & 0.37 \\
\hline$t_{4}=210 \mathrm{sec}$ & $-3.14+/-1.84$ & 0.15 & $-3.38+/-1.9$ & 0.14 \\
\hline$t_{5}=300 \mathrm{sec}$ & $-3.78+/-1.76$ & 0.085 & $-2.23+/-2.69$ & 0.45 \\
\hline$t_{6}=330 \mathrm{sec}$ & \multicolumn{4}{|c|}{ Conjunctival instillation of timolol $2.5 \mathrm{mM}$} \\
\hline$t_{7}=420 \mathrm{sec}$ & $-8.25+/-2.46$ & 0.02 & $-1.92+/-4.19$ & 0.67 \\
\hline $\mathrm{t}_{8}=480 \mathrm{sec}$ & $-9.22+/-2.82$ & 0.022 & $-2.25+/-5,24$ & 0.69 \\
\hline$t_{9}=510 \mathrm{sec}$ & $-10.15+/-4,59$ & 0.078 & $2,11+/-3.83$ & 0.61 \\
\hline$t_{10}=600 \mathrm{sec}$ & $-9.26+/-2.53$ & 0.015 & $-1.22+/-4.23$ & 0.78 \\
\hline$t_{11}=630 \mathrm{sec}$ & $-10.58+/-3.5$ & 0.029 & $-1.87+/-3.45$ & 0.61 \\
\hline
\end{tabular}


having an effect on the diameter of iris veins. Our results suggest that there is a catecholaminergic vasodilator tonus present in iris arteries and not in iris veins, which, in our experimental conditions (ketamine anesthesia), is probably achieved through $\beta_{2}$-adrenergic receptors.

\section{References}

1. Klabunde, Richard E. Chapter 5: Vascular Function in Richard E. Klabunde Cardiovascular Physiology Concepts. Lippincott Williams \& Wilkins/Wolters Kluwer, 2012, 93-109.

2. Westfall, Thomas $\mathrm{C}$ et al. Chapter 8: Neurotransmission: The Autonomic and Somatic Motor Nervous Systems in Brunton, Laurence L., et al. Goodman \& Gilman's the Pharmacological Basis of Therapeutics. McGraw-Hill Education, 2018, 115-147.

3. Malmfors T. The adrenergic innervation of the eye as demonstrated byfluorescence microscopy. Acta Physiol Scand. 1965 Nov;65(3):259-67.

4. McDougal DH, Gamlin PD. Autonomic control of the eye. Compr Physiol. 2015Jan;5(1):439-73.

5. Szumny D, Szeląg A. The influence of new beta-adrenolytics nebivolol andcarvedilol on intraocular pressure and iris blood flow in rabbits. Graefes ArchClin Exp Ophthalmol. 2014 Jun; 252(6):917-23.

6. Szalay J, Fliegenspan J, Zaager A, Tobin G, Cross S. Effect of beta adrenergic agents on blood vessels of the rat iris. I. Permeability to carbon particles. ExpEye Res. 1980 Sep;31(3):289-97.

\section{Compliance with ethics requirements:}

The authors declare no conflict of interest regarding this article.

The authors declare that all the procedures and experiments of this study respect the ethical standards in the Helsinki Declaration of 1975, as revised in 2008(5), as well as the national law. Informed consent was obtained from all the patients included in the study.

7. Virdi PS, Hayreh SS. Effects of pilocarpine, timolol, epifrin and thymoxamine on iris vessels in rhesus monkeys. Int Ophthalmol. 1984 Jan;7(1):3-10.

8. Fischer MJ, Uchida S, Messlinger K. Measurement of meningeal blood vesseldiameter in vivo with a plug-in for ImageJ. Microvasc Res. 2010 Sep;80(2):258-66.

9. Fulga I, Cap. 1: Farmacodinamia generală in Fulga, Ion (sub redacția), Farmacologie, ed. a II-a revizuită și adăugită, Ed. Medicală, București, 2015, 38-39.

10. Richard A. Bond, David B. Bylund, Douglas C. Eikenburg, J. Paul Hieble, Rebecca Hills, Kenneth P. Minneman, Sergio Parra. Adrenoceptors: B2-adrenoceptor. Last modified on 23/02/2018. Accessed on 16/05/2018. IUPHAR/BPS Guide to PHARMACOLOGY, http://www.guidetopharmacology.org/GRAC/ObjectDisp layForward?objectld=29.

11. Zugravu A. et al., Cap. 12: Anestezice generale in Fulga, Ion (sub redacția), Farmacologie, ed. a II-a revizuită și adăugită, Ed. Medicală, București, 2015, 196-197. 
